\title{
Effect of Soil Working Techniques on Moisture Conservation, Growth, Yield and Fruit Cracking of Pomegranate (Punica granatum L.) cv. Kandhari
}

\author{
Prativa Sahu $^{1 *}$ and N. Sharma ${ }^{2}$ \\ ${ }^{1}$ ICAR- Indian Institute of Water Management, Bhubaneswar, Odisha-751023, India \\ ${ }^{2}$ Department of Fruit Science, Dr. Y.S. Parmar University of Horticulture and Forestry, \\ Nauni, Solan (H.P.) 173 230, India \\ *Corresponding author
}

\section{Keywords \\ Pomegranate, Soil working techniques, Crescent bund with open catchment pits, Soil moisture conservation, Growth, Fruit cracking}

Article Info

Accepted:

10 December 2018 Available Online: 10 January 2019

\section{A B S T R A C T}

An experiment on soil working techniques like CBOC (crescent bund with open catchment pits), mulching and pre-harvest spray of forchlorfenuron and boron was carried out on seven-year-old plants of pomegranate cultivar Kandhari trained as four stems grown under rainfed conditions of Himachal Pradesh. Experimental plants were subjected to 11 treatments, viz., mulching, $\mathrm{CBOC}$, $\mathrm{CPPU}$ (forchlorfenuron) at 5 or $10 \mathrm{ppm}, \mathrm{H}_{3} \mathrm{BO}_{3}$ at 0.2 or $0.4 \%$, mulching + CPPU at $5 \mathrm{ppm}$ or $\mathrm{H}_{3} \mathrm{BO}_{3}$ at $0.2 \%, \mathrm{CBOC}+\mathrm{CPPU}$ at $5 \mathrm{ppm}$ or $\mathrm{H}_{3} \mathrm{BO}_{3}$ at $0.2 \%$ and control. These treatments were applied in mid-March (soil working techniques) and mid-May (forchlorfenuron and boron). Between the two applied soil working techniques, crescent bund with open catchments pits conserved higher soil moisture content at all the observation dates than mulching. Growth parameters like plant height, plant spread, trunk girth and annual shoot growth were observed significantly higher under the treatment $\mathrm{CBOC}+\mathrm{H}_{3} \mathrm{BO}_{3}$ at $0.2 \%$ due to higher moisture availability. However, leaf area and leaf chlorophyll content were recorded significantly higher under the treatment $\mathrm{CBOC}+\mathrm{CPPU}$ at $5 \mathrm{ppm}$. Physiological characteristics such as photosynthetic rate and transpiration rate were higher in the plant under crescent bund with open catchment pits. The extent of fruit cracking was reduced to the lowest level (2.8\%) from $11.67 \%$ in control and highest fruit yield $(26.8 \mathrm{Kg} / \mathrm{plant})$ was recorded when the plants were given foliar application of CPPU at $5 \mathrm{ppm}$ under CBOC. These results suggest that, soil working technique- crescent bund with open catchment pit can be employed to conserve higher soil moisture in rainfed conditions for improving growth and production of pomegranate.

\section{Introduction}

Pomegranate (Punica granatum L.) is one of the most historic fruits and considered as a symbol of fertility and often quoted in the theological texts (Mars, 2000). Its fruit has wide consumer preference for its attractive, juicy, sweet-acidic and refreshing arils. Though pomegranate was originally adapted to Mediterranean climate, but it has also 
flourished well under hot dry summers with cool winters. The foot hills of Himachal Pradesh comprise sub-tropical sub-montane and valley areas of Shivalik hills hold tremendous scope for its cultivation. In Himachal Pradesh, pomegranate cultivation has slowly picked up by farmers in the districts of Kullu, Una, Hamirpur, parts of Chamba, Kangra, Bilaspur, Sirmour and Solan for diversification in horticulture. The plants suffer acute moisture stress leading to fruit cracking at their critical stages of growth and development due to erratic and uneven rains under rainfed conditions. Fruit cracking is a physiological disorder, generally associated with differential rate of growth of fruit skin/rind and fruit aril. It may be due to imbalance soil moisture in mature fruits and boron deficiency in immature fruits. It therefore becomes imperative to conserve every drop of rain water in the field using insitu moisture conservation techniques to enhance soil moisture storage for inducing good vegetative growth and productivity, lowest fruit cracking by improving their morphological and physiological status. Some practices like mulching of tree basins and soil working techniques like, crescent bund with open catchment pits (Sharma and Singh, 2010) have been found to be useful in many crops for conserving soil moisture.

Therefore, the present study was undertaken to ascertain the effect of mulching, soil working technique 'crescent bund with open catchment pits' and foliar application of CPPU and boron on pomegranate cv. Kandhari with an objective to evaluate the morphological and physiological status, fruit cracking and yield potentials of pomegranate through conserving soil moisture under rainfed conditions.

\section{Materials and Methods}

The present investigation was carried out in the experimental orchard of the Department of
Fruit Science, Dr Y.S. Parmar University of Horticulture and Forestry, Nauni, Solan. For this study, 33 plants of 7-year-old pomegranate trained as four stem system and spaced $4 \mathrm{~m} \mathrm{x} 4 \mathrm{~m}$ apart were selected. Soil at the experimental site was silty loam; having $6.81 \mathrm{pH}, 1.76 \%$ organic carbon content, $8.00 \%$ permanent wilting point, $25.50 \%$ field capacity and $1.10 \mathrm{~g} \mathrm{~cm}-3$ bulk density. Experimental plants were subjected to 11 treatments, viz. mulching (10 $\mathrm{cm}$ thick hey), CBOC (crescent bund with open catchment pits), CPPU (forchlorfenuron) at 5 or $10 \mathrm{ppm}$, $\mathrm{H}_{3} \mathrm{BO}_{3}$ at 0.2 or $0.4 \%$, Mulching + CPPU at 5 ppm or $\mathrm{H}_{3} \mathrm{BO}_{3}$ at $0.2 \%, \mathrm{CBOC}+\mathrm{CPPU}$ at 5 ppm or $\mathrm{H}_{3} \mathrm{BO}_{3}$ at $0.2 \%$ and control (no treatment). These treatments were applied separately in mid-March (in-situ soil moisture conservation) and mid -May (forchlorfenuron and boron). All the treatments were replicated three times in a randomized block design.

Soil moisture $(\%)$ were taken with the help of AquaPro $®$ soil moisture profiler at 15 days intervals during the growing season from 1st April to 15 th July at $15,30,45 \mathrm{~cm}$ depths. The access tubes fitted $1 \mathrm{~m}$ away from the trunk. The percentage increase in growth parameters, viz., plant height, plant spread, trunk girth, and annual shoot growth were observed in the field before the commencement of the growth and after the cessation of growth in autumn. Simultaneously, 20 fully expended leaves were collected at random from the periphery of each plant in the month of August and their area $\left(\mathrm{cm}^{2}\right)$ was measured with the help of LICor 3100 leaf area meter. The observations on photosynthetic and transpiration rates of ten mature leaves randomly selected from all over the periphery of each experimental plant were taken with the help of LCA4 portable photosynthesis system (ADC, UK) in midJune between 10:00 and 11:00 AM (Hunter and Proctor, 2). The results were averaged and expressed in $\mu \mathrm{mol} \mathrm{m} \mathrm{m}^{-2}$ and $\mathrm{mmol} \mathrm{m} \mathrm{m}^{-2} \mathrm{~s}^{-1}$ respectively. Extraction of chlorophyll was 
carried out in 80 per cent acetone as per procedure described by Sestak et al., (9) during the month of July. The number of the fruits cracked on each experimental plant were counted periodically during the entire fruiting season and expressed in per cent. Fruit yield $(\mathrm{kg} / \mathrm{tree})$ was determined on the basis of total weight of fruits harvested from the each experimental plant. The data were subjected to statistical analysis as per the procedure outlined by Panse and Sukhatme (7).

\section{Results and Discussion}

Soil moisture contents under the plant basins fluctuated greatly with dry spells and erratic rainfall cycles $(1,0,0,2.7,48.2,0,116.6$, 52.2, 280.7, $203.9 \mathrm{~mm}$ rainfall in 15th March, 1st April, 15th April, 1st May, 15th May, 1st June, 15th June, 1st July, 15th July, respectively during the course of investigation. However during all the observation dates, maximum soil moisture contents of $18.01 \%$ at 0-15 cm soil depth; $18.88 \%$ at $15-30 \mathrm{~cm}$ soil depth and $19.03 \%$ at $30-45 \mathrm{~cm}$ soil depth were recorded under the treatment $\mathrm{CBOC}+\mathrm{CPPU}$ at 5 ppm (Tables 1-3).

Soil under mulching also maintained more moisture level. CBOC might have effectively prevented any surface water runoff and facilitated to collect runoff water in the pits and hence resulted in higher soil moisture conservation in rhizosphere of plant roots as compared to mulching. At $15 \mathrm{~cm}$ soil depth the lowest soil moisture content $(8.96 \%)$ was recorded on 1st April and increased steadily from 1st of May $(9.06 \%)$ and reached at the significantly highest level on 15th July $(16.15 \%)$. The interaction effect of treatments with soil moisture levels during different period was also found to be significant. At 45 $\mathrm{cm}$ soil depth the maximum moisture content $(19.03 \%)$ was recorded under the treatment $\mathrm{T}_{9}$ (CBOC + CPPU at $5 \mathrm{ppm})$ on 15 th of July, which was significantly at par with the treatment of $\mathrm{T}_{10}\left(\mathrm{CBOC}+\mathrm{H}_{3} \mathrm{BO} \mathrm{O}_{3}\right.$ at $\left.0.2 \%\right)$ on 15 th of July $(18.83 \%)$ and $\mathrm{T}_{2}$ (Crescent bund with open catchment pits) on 15thof July $(18.97 \%)$. The lowest soil moisture contents in control were recorded on 1st of May. Lower soil profile between the depths of 15-30 and $30-45 \mathrm{~cm}$ happened to store more moisture during wet months of the year as compared to dry months and upper soil profile $(0-15 \mathrm{~cm})$. Such results have earlier been reported by Farmahan and Sharma (1) in pomegranate cv. Ganesh, and Singh and Sharma (11) in olive.

Under rain fed conditions, the performance of pomegranate can greatly be improved by shaping the soil surface in the immediate vicinity of the plant, so that the run-off water is collected at root zone for inducing good vegetative growth and productivity. The basic principle is to construct mini water catchments that collect water from one specific area even if light rain occurs to raise the soil moisture status. Such moisture conservation is diverted to the Rhizopher of the fruit trees for its efficient utilization at critical stages of growth and development.

The maximum increase in plant height $(27.06 \%)$ was observed under the treatment $\mathrm{T}_{10}\left(\mathrm{CBOC}+\mathrm{H}_{3} \mathrm{BO}_{3}\right.$ at $0.2 \%$ ), closely followed by $\mathrm{T}_{8}$ (Mulching $+\mathrm{H}_{3} \mathrm{BO}_{3}$ at $0.2 \%$ ). The minimum annual increment plant height $(13.15 \%)$ was recorded under the control (Table 4). Plant spread in both North-South $(33.80 \%)$ and East -West $(32.75 \%)$ direction was significantly higher in plants under the treatment $\mathrm{CBOC}+\mathrm{H}_{3} \mathrm{BO}_{3}$ at $0.2 \%$ in comparison to all other treatments (Table 4). However, the highest increase in trunk girth $(27.92 \%)$ was noticed in plants given the treatment of foliar treatment of boron at $0.2 \%$ in combination with soil working technique 'crescent bund with open catchment pits $\left(\mathrm{T}_{10}\right)$. Significantly highest shoot growth $(43.15 \mathrm{~cm})$ was recorded in plants under $\mathrm{CBOC}$ when sprayed with boric acid at $0.2 \%$. 
Int.J.Curr.Microbiol.App.Sci (2019) 8(1): 1343-1350

Table.1 Effect of in-situ moisture conservation, forchlorfenuron and boron on soil moisture storage at $15 \mathrm{~cm}$ soil depth in pomegranate $\mathrm{cv}$. Kandhari

\begin{tabular}{|l|c|c|c|c|c|c|c|c|c|}
\hline Treatment & 1 st & 15 th & $\begin{array}{l}1 \text { st } \\
\text { May }\end{array}$ & 15 th & 1 st & 16 th & 1 st & 15 th & Mean \\
\hline & April & April & & May & June & June & July & July & \\
\hline $\mathrm{T}_{1}:$ Mulching with hay $(10 \mathrm{~cm})$ & 8.05 & 8.22 & 8.79 & 11.34 & 11.03 & 14.95 & 14.93 & 16.22 & 11.69 \\
\hline $\mathrm{T}_{2}:$ Crescent bund with open & 9.53 & 9.81 & 10.57 & 12.29 & 12.14 & 16.29 & 16.35 & 17.91 & 13.15 \\
\hline catchment pits $(\mathrm{CBOC})$ & & & & & & & & & \\
\hline $\mathrm{T}_{3}: \mathrm{CPPU}$ at $5 \mathrm{ppm}$ & 7.31 & 6.47 & 6.40 & 8.78 & 8.62 & 11.20 & 11.84 & 12.98 & 9.20 \\
\hline $\mathrm{T}_{4}: \mathrm{CPPU}_{4}$ at $10 \mathrm{ppm}$ & 7.12 & 6.54 & 6.51 & 8.91 & 8.75 & 11.13 & 11.79 & 12.27 & 9.13 \\
\hline $\mathrm{T}_{5}: \mathrm{H}_{3} \mathrm{BO}_{3}$ at $0.2 \%$ & 7.26 & 6.44 & 6.33 & 8.63 & 8.47 & 11.29 & 11.98 & 12.93 & 9.17 \\
\hline $\mathrm{T}_{6}: \mathrm{H}_{3} \mathrm{BO}_{3}$ at $0.4 \%$ & 7.09 & 6.91 & 6.44 & 8.79 & 8.60 & 11.10 & 11.71 & 12.21 & 9.11 \\
\hline $\begin{array}{l}\mathrm{T}_{7}: \mathrm{Mulching}+\mathrm{CPPU} \text { at } 5 \\
\text { ppm }\end{array}$ & 8.11 & 8.63 & 8.72 & 11.17 & 11.00 & 14.06 & 14.59 & 15.88 & 11.52 \\
\hline $\mathrm{T}_{8}:$ Mulching $+\mathrm{H}_{3} \mathrm{BO}_{3}$ at $0.2 \%$ & 8.12 & 8.66 & 8.80 & 11.25 & 11.08 & 14.09 & 14.62 & 15.90 & 11.57 \\
\hline $\mathrm{T}_{9}: \mathrm{CBOC}+\mathrm{CPPU}_{4}$ at $5 \mathrm{ppm}$ & 9.47 & 9.97 & 10.13 & 12.13 & 12.05 & 16.00 & 16.29 & 18.01 & 13.21 \\
\hline $\mathrm{T}_{10}: \mathrm{CBOC}+\mathrm{H}_{3} \mathrm{BO}_{3}$ at $0.2 \%$ & 9.51 & 9.88 & 10.09 & 12.25 & 12.11 & 15.98 & 16.17 & 17.92 & 13.17 \\
\hline $\mathrm{T}_{11}: \mathrm{Control}$ & 7.20 & 6.30 & 6.35 & 8.68 & 8.60 & 11.10 & 11.50 & 12.00 & 8.97 \\
\hline Mean & 8.07 & 7.98 & 8.10 & 10.38 & 10.22 & 13.38 & 13.80 & 14.93 & \\
\hline
\end{tabular}

$\mathrm{CD}_{0.05}$

Treatment (T): 0.08; Day (D): 0.07; T × D: 0.24

Table.2 Effect of in-situ soil moisture conservation, forchlorfenuron and boron on soil moisture storage at $30 \mathrm{~cm}$ soil depth in pomegranate $\mathrm{cv}$. Kandhari

\begin{tabular}{|l|c|c|c|c|c|c|c|c|c|}
\hline Treatment & 1st & 15 th & 1 1st & 15 th & 1 st & 16 th & 1 st & 15 th & Mean \\
\hline & April & April & May & May & June & June & July & July & \\
\hline $\mathrm{T}_{1}:$ Mulching with hay $(10 \mathrm{~cm})$ & 8.90 & 9.03 & 9.17 & 12.53 & 12.00 & 16.03 & 14.85 & 15.89 & 12.3 \\
\hline $\mathrm{T}_{2}:$ Crescent bund with open & 9.96 & 10.11 & 11.02 & 14.48 & 13.84 & 17.92 & 16.03 & 16.93 & 13.79 \\
\hline catchment pits $(\mathrm{CBOC})$ & & & & & & & & & \\
\hline $\mathrm{T}_{3}: \mathrm{CPPU}$ at $5 \mathrm{ppm}$ & 7.75 & 7.09 & 6.91 & 9.71 & 9.56 & 12.41 & 11.72 & 12.56 & 9.71 \\
\hline $\mathrm{T}_{4}: \mathrm{CPPU}^{2}$ at $10 \mathrm{ppm}$ & 7.63 & 6.99 & 6.77 & 9.68 & 9.39 & 12.19 & 11.68 & 12.23 & 9.59 \\
\hline $\mathrm{T}_{5}: \mathrm{H}_{3} \mathrm{BO}_{3}$ at $0.2 \%$ & 7.68 & 6.94 & 6.54 & 9.53 & 9.38 & 12.33 & 11.71 & 12.44 & 9.61 \\
\hline $\mathrm{T}_{6}: \mathrm{H}_{3} \mathrm{BO}_{3}$ at $0.4 \%$ & 7.59 & 6.92 & 6.68 & 9.78 & 9.61 & 12.27 & 11.52 & 12.21 & 9.54 \\
\hline $\begin{array}{l}\mathrm{T}_{7}: \text { Mulching }+\mathrm{CPPU} \text { at } 5 \\
\text { ppm }\end{array}$ & 8.92 & 9.04 & 9.07 & 12.12 & 11.37 & 14.22 & 13.86 & 15.09 & 11.71 \\
\hline $\mathrm{T}_{8}:$ Mulching $+\mathrm{H}_{3} \mathrm{BO}_{3}$ at $0.2 \%$ & 8.95 & 9.10 & 9.30 & 12.65 & 11.21 & 14.00 & 13.92 & 15.17 & 11.79 \\
\hline $\mathrm{T}_{9}: \mathrm{CBOC}+\mathrm{CPPU}_{2}$ at 5 ppm & 9.94 & 10.76 & 10.89 & 14.06 & 14.00 & 16.70 & 16.09 & 18.88 & 13.92 \\
\hline $\mathrm{T}_{10}: \mathrm{CBOC}+\mathrm{H}_{3} \mathrm{BO}_{3}$ at $0.2 \%$ & 9.98 & 10.81 & 10.92 & 13.99 & 13.83 & 16.46 & 16.23 & 18.73 & 13.87 \\
\hline $\mathrm{T}_{11}:$ Control & 8.00 & 6.88 & 6.78 & 9.79 & 9.61 & 12.50 & 12.12 & 12.25 & 9.74 \\
\hline Mean & 8.66 & 8.52 & 8.55 & 11.67 & 11.25 & 14.28 & 13.61 & 15.76 & \\
\hline
\end{tabular}

$\mathrm{CD}_{0.05}$

Treatment (T): 0.69; Day (D): 0.05; T × D: 1.96 
Int.J.Curr.Microbiol.App.Sci (2019) 8(1): 1343-1350

Table.3 Effect of in-situ soil moisture conservation, forchlorfenuron and boron on soil moisture storage at $45 \mathrm{~cm}$ soil depth in pomegranate $\mathrm{cv}$. Kandhari

\begin{tabular}{|l|c|c|c|c|c|c|c|c|c|}
\hline Treatment & 1st & 15 th & 1 st & 15 th & 1 st & 16 th & 1 st & 15 th & Mean \\
\hline & April & April & May & May & June & June & July & July & \\
\hline $\mathrm{T}_{1}:$ Mulching with hay $(10 \mathrm{~cm})$ & 9.09 & 9.48 & 9.61 & 12.91 & 12.15 & 16.93 & 15.23 & 17.00 & 12.80 \\
\hline $\mathrm{T}_{2}:$ Crescent bund with open & 10.06 & 10.96 & 11.24 & 14.76 & 14.35 & 18.64 & 17.94 & 18.97 & 14.62 \\
\hline catchment pits $(\mathrm{CBOC})$ & & & & & & & & & \\
\hline $\mathrm{T}_{3}: \mathrm{CPPU}$ at $5 \mathrm{ppm}$ & 8.00 & 7.95 & 7.67 & 10.88 & 10.17 & 14.21 & 13.91 & 14.97 & 10.97 \\
\hline $\mathrm{T}_{4}: \mathrm{CPPU}^{2} 10 \mathrm{ppm}$ & 8.25 & 7.18 & 7.06 & 10.26 & 10.01 & 13.97 & 13.44 & 14.25 & 10.55 \\
\hline $\mathrm{T}_{5}: \mathrm{H}_{3} \mathrm{BO}_{3}$ at $0.2 \%$ & 8.06 & 7.70 & 7.52 & 10.63 & 10.36 & 14.02 & 13.86 & 14.73 & 10.86 \\
\hline $\mathrm{T}_{6}: \mathrm{H}_{3} \mathrm{BO}_{3}$ at $0.4 \%$ & 8.49 & 7.66 & 7.47 & 10.58 & 10.21 & 14.00 & 13.21 & 14.69 & 10.79 \\
\hline $\mathrm{T}_{7}: \mathrm{Mulching}+\mathrm{CPPU}$ at $5 \mathrm{ppm}$ & 9.12 & 9.27 & 9.33 & 12.39 & 11.94 & 15.93 & 15.23 & 16.04 & 12.41 \\
\hline $\mathrm{T}_{8}:$ Mulching $+\mathrm{H}_{3} \mathrm{BO}_{3}$ at $0.2 \%$ & 9.15 & 9.84 & 9.95 & 13.02 & 12.83 & 16.00 & 15.29 & 16.12 & 12.78 \\
\hline $\mathrm{T}_{9}: \mathrm{CBOC}+\mathrm{CPPU}_{5} 5 \mathrm{ppm}$ & 10.08 & 11.31 & 11.44 & 14.65 & 14.54 & 18.77 & 18.00 & 19.03 & 14.73 \\
\hline $\mathrm{T}_{10}: \mathrm{CBOC}+\mathrm{H}_{3} \mathrm{BO}_{3}$ at $0.2 \%$ & 10.06 & 11.27 & 11.40 & 14.59 & 14.28 & 18.47 & 17.29 & 18.83 & 14.52 \\
\hline $\mathrm{T}_{11}:$ Control & 8.23 & 7.10 & 7.01 & 9.98 & 9.83 & 12.91 & 12.33 & 13.01 & 10.05 \\
\hline Mean & 8.96 & 9.07 & 9.06 & 12.24 & 11.88 & 15.80 & 15.07 & 16.15 & \\
\hline
\end{tabular}

$\mathrm{CD}_{0.05}$

Treatment (T): 1.23; Days (D): 1.11; T × D: 2.57

Table.4 Effect of in-situ soil moisture conservation, forchlorfenuron and boron on plant height, plant spread and trunk girth, shoot growth and leaf area of pomegranate cv. Kandhari

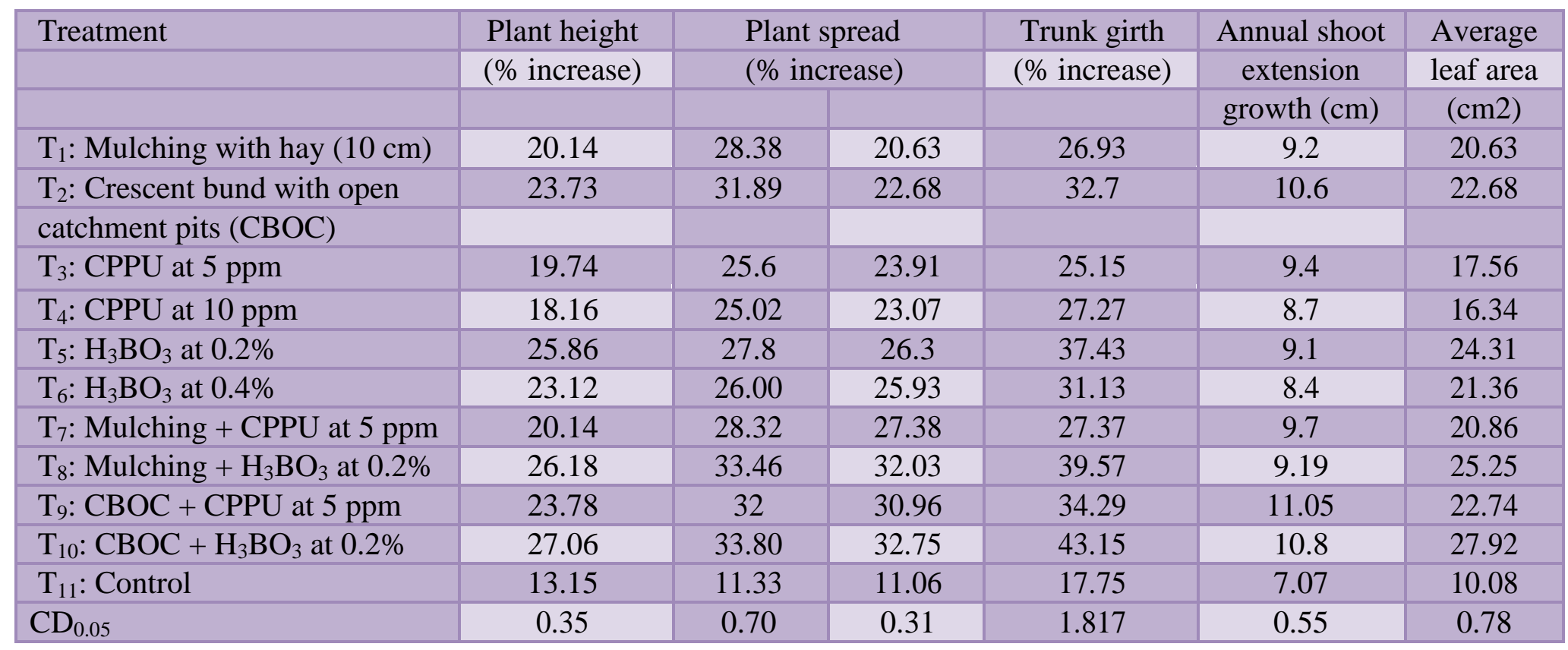


Table.5 Effect of in-situ soil moisture conservation, forchlorfenuron and boron on transpiration rate, photosynthetic rate, leaf chlorophyll content, fruit cracking and fruit yield of pomegranate $\mathrm{cv}$.

Kandhari

\begin{tabular}{|c|c|c|c|c|c|}
\hline Treatment & $\begin{array}{l}\text { Transpiration } \\
\text { rate } \\
\left(\mathrm{mmol} \mathrm{m}^{-2} \mathrm{~s}^{-1}\right)\end{array}$ & $\begin{array}{c}\text { Photosynthetic } \\
\text { rate } \\
\left(\mu \mathrm{mol} \mathrm{m}{ }^{-2} \mathrm{~s}^{-1}\right)\end{array}$ & $\begin{array}{l}\text { Leaf chlorophyll } \\
\text { content } \\
\text { (mg/g of fr. wt.) }\end{array}$ & $\begin{array}{l}\text { Fruit } \\
\text { cracking } \\
(\%)\end{array}$ & $\begin{array}{l}\text { Fruit yield } \\
(\mathrm{kg} / \text { tree })\end{array}$ \\
\hline $\begin{array}{l}\mathrm{T}_{1} \text { : Mulching with hay (10 } \\
\mathrm{cm})\end{array}$ & 0.280 & 12.19 & 1.92 & 5.2 & 21.2 \\
\hline $\mathrm{T}_{2}$ : Crescent bund with open & 0.327 & 13.88 & 1.99 & 3.9 & 22.9 \\
\hline catchment pits (CBOC) & & & & & \\
\hline $\mathrm{T}_{3}: \mathrm{CPPU}$ at $5 \mathrm{ppm}$ & 0.183 & 11.56 & 2.61 & 4.1 & 22.1 \\
\hline $\mathrm{T}_{4}: \mathrm{CPPU}$ at $10 \mathrm{ppm}$ & 0.141 & 10.09 & 2.57 & 4.53 & 20.6 \\
\hline $\mathrm{T}_{5}: \mathrm{H}_{3} \mathrm{BO}_{3}$ at $0.2 \%$ & 0.235 & 11.94 & 2.3 & 5.1 & 21.9 \\
\hline $\mathrm{T}_{6}: \mathrm{H}_{3} \mathrm{BO}_{3}$ at $0.4 \%$ & 0.223 & 10.68 & 2.21 & 5.6 & 20.2 \\
\hline $\begin{array}{l}\mathrm{T}_{7} \text { : Mulching + CPPU at } 5 \\
\text { ppm }\end{array}$ & 0.293 & 13.13 & 2.78 & 3.5 & 24.9 \\
\hline $\begin{array}{l}\mathrm{T}_{8}: \text { Mulching }+\mathrm{H}_{3} \mathrm{BO}_{3} \text { at } \\
0.2 \%\end{array}$ & 0.396 & 14.39 & 2.41 & 3.8 & 23.3 \\
\hline $\mathrm{T}_{9}: \mathrm{CBOC}+\mathrm{CPPU}$ at $5 \mathrm{ppm}$ & 0.339 & 14.23 & 2.93 & 2.8 & 26.8 \\
\hline $\mathrm{T}_{10}: \mathrm{CBOC}+\mathrm{H}_{3} \mathrm{BO}_{3}$ at $0.2 \%$ & 0.413 & 14.99 & 2.45 & 3.2 & 24.02 \\
\hline $\mathrm{T}_{11}$ : Control & 0.095 & 8.73 & 1.41 & 11.67 & 14.27 \\
\hline $\mathrm{CD}_{0.05}$ & 0.150 & 0.28 & 0.05 & 0.28 & 0.46 \\
\hline
\end{tabular}

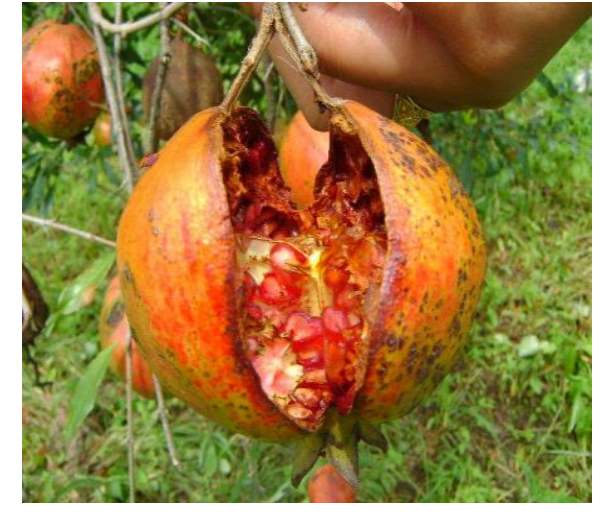

Fruit cracking in mature

The minimum shoot growth $(17.75 \mathrm{~cm})$ was however, observed in control plants (Table 4). These results can be attributed to the availability of more moisture under $\mathrm{CBOC}$ and mulching at all soil depths and role of boron in $\mathrm{N}$ metabolism, hormone movement

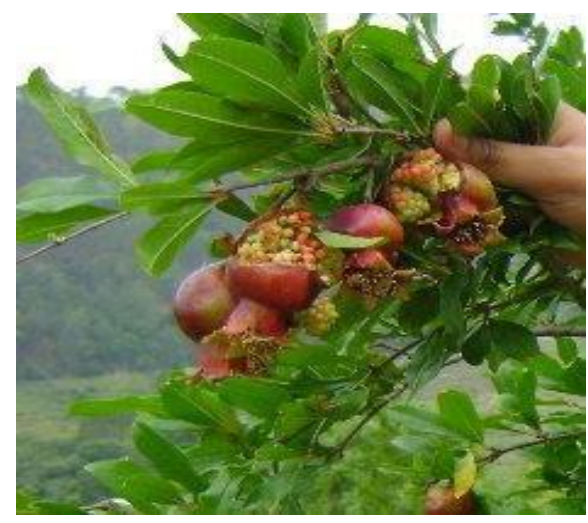

Fruit cracking in younger

action and cell division (Russel, 8). The leaf area $\left(11.05 \mathrm{~cm}^{2}\right)$, accumulation of chlorophylls $(2.93 \mathrm{mg} / 100 \mathrm{~g}$ fresh weight) was significantly higher in the leaves of plants under the treatment $\mathrm{CBOC}+\mathrm{CPPU}$ at $5 \mathrm{ppm}$ (Tables 4 and 5). 
The present findings are in agreement with those of Iersel and Nemali (3), and Jyothi and Raijadhav (4) who observed that higher soil moisture level favoured more leaf growth in Rangapur lime.

The CPPU is an urea based cytokinin which induced the activity of invertase enzyme in conversion of lipids to glucose, fructose (Notodimedjo, 6) and as solute concentration increases and OP becomes negative, thus resulting in more uptake of water, leading to better leaf expansion. Cytokinin helps in the retention of chlorophyll and stimulates the nutrient mobilization and thus might have resulted in the accumulation of more chlorophyll in treated leaves. Photosynthetic rate (Table 5) was significantly higher (14.99 $\mu \mathrm{mol} \mathrm{m} \mathrm{m}^{-2} \mathrm{~s}^{-1}$ in tree under the treatment of CBOC in comparison to other treatments and minimum photosynthetic rate was observed in the tree under the traditional basin system $\left(8.73 \mu \mathrm{mol} \mathrm{m} \mathrm{m}^{-2} \mathrm{~s}^{-1}\right)$. Likewise, transpiration rate (Table 5) was significantly higher in the trees under CBOC system (0.413 $\left.\mathrm{mmol} \mathrm{m} \mathrm{s}^{-2}\right)$.

Fruit cracking was reduced to the lowest level (2.8\%) when the plants grown under CBOC and given foliar application of CPPU at 5 ppm $\left(\mathrm{T}_{9}\right)$ or $\mathrm{H}_{3} \mathrm{BO}_{3}$ at $0.2 \%\left(\mathrm{~T}_{10}\right)$. The highest fruit yield $(26.8 \mathrm{~kg} /$ plant $)$ was recorded under $\mathrm{T}_{9}$ (CBOC + CPPU at $5 \mathrm{ppm}$ ), closely followed by $\mathrm{T}_{7}$ (Mulching + CPPU at $5 \mathrm{ppm}$ ) (Table 5). The fruit yield was however, significantly lowest in control (14.27 kg/ plant). As CBOC maintained higher soil moisture level soil during the fruit development (Tables 1-3), which consequently might have decreased fruit cracking. The growth regulator CPPU might have stimulated overall growth of pomegranate fruits and thereby reduced fruit cracking in this study. The findings are in agreement with those of Singh et al., (10), and Navarro et al., (5).
From the ongoing study it can be concluded that soil working technique- crescent bund with open catchment pit can be employed to conserve more soil moisture, maintaining photosynthesis, improving growth and production of pomegranate in rain fed conditions. In-situ moisture conservation technique CBOC in combination with CPPU $5 \mathrm{ppm}$ in mid May decreased fruit cracking and increased yield.

\section{References}

1. Farmahan, H.L. and Sharma, N. 2005. Effect of soil working techniques on moisture conservation and productivity in pomegranate cv. Ganesh under rainfed conditions. Acta Hort. 96: 26976

2. Hunter, D.M. and Proctor, J.T.A. 1994. Paclobutrazol reduces photosynthetic carbon dioxide uptake rate in grape vines. J. American Soc. Hort. Sci. 119: 486-91.

3. Iersel, M.W. and Nemali, K.S. 2004. Effect of soil moisture on growth parameters of Longan. HortSci. 39: 1298-1301.

4. Jyothi Hadli and Raijadhav, S.B. 2004. Effect of soil moisture stress on growth and physiological attributes of different strains of Rangpur lime. J. Maharashtra Agric. Univ. 29: 263-66.

5. Navarro, O.M., Retamales, F.J. and Defilippi, B.B. 2001. Effect of cluster thinning and the application of synthetic cytokinin CPPU on the quality of table grapes treated with two sources of gibberellins. Agric. Technica, 61: 1525.

6. Notodimedjo, S. 2000. Effect of GA3, NAA and CPPU on fruit retention, yield and quality of mango (cv. Arumanis) in East Java. Acta Hort. 509: 587-600. 
7. Panse, V.G. and Sukhatme, P.V. 1976. Statistical Methods for Agricultural Workers, ICAR, New Delhi.

8. Russel, D.A. 1957. Boron and soil fertility. In: The Yearbook of Agriculture- USDA, Washington, D.C.

9. Sestak, Z., Catschy, J. and Ganier, G.G. 1971. Plant photosynthetic production. Manual of Methods. N.V. Pub., the Hague.
10. Singh, D.B., Sharma, B.D. and Bhargava, R. 2003. Effect of boron and GA3 to control fruit cracking in pomegranate (Punica granatum). Curr. Agric. 27: 125-27.

11. Singh, K. and Sharma. N. 2010. Effect of in situ moisture conservation on morphology, physiology and production of olives under rainfed conditions. Indian J. Hort. 64: 364-66.

\section{How to cite this article:}

Prativa Sahu and N. Sharma. 2019. Effect of Soil Working Techniques on Moisture Conservation, Growth, Yield and Fruit Cracking of Pomegranate (Punica granatum L.) cv. Kandhari. Int.J.Curr.Microbiol.App.Sci. 8(01): 1343-1350.

doi: https://doi.org/10.20546/ijcmas.2019.801.143 